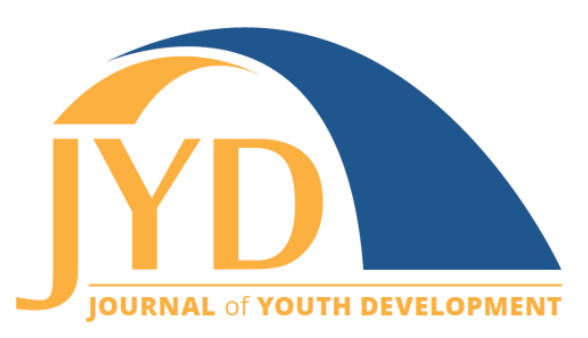

http://jyd. pitt. edu/ | Vol. 14 Issue 2 DOI 10.5195/jyd.2019.704 | ISSN 2325-4017 (online)

\title{
Leisure Experiences and Social Support Systems of Latino Students With DACA Status
}

\author{
C. Austin Langley \\ Davidson College \\ aulangley@davidson.edu
}

Gwynn M. Powell

Clemson University

gwynnp@clemson.edu

Toni Liechty

University of Illinois at Urbana-Champaign

tliechty@illinois.edu

William Haller

Clemson University

whaller@clemson.edu

Denise Anderson

Clemson University

dander2@clemson.edu

\begin{abstract}
The purpose of this study was to gain a better understanding of the leisure experiences of undocumented Latino young adults with Deferred Action for Childhood Arrivals (DACA) status in order to note any potential links between leisure experience and success in reaching higher education. This population faces a unique set of challenges in their transition to adulthood and their pursuit of and access to higher education. Research suggests that 3 common factors among undocumented young adults who have been successful in reaching higher education are extra-familial mentors, positive social supports, and supplementary educational programming. This study used these 3 factors and the principles of contact theory to examine leisure experiences of undocumented young adults with DACA status. Qualitative semistructured interviews were conducted with 7 young adults with DACA status who were enrolled in higher education. The data were transcribed verbatim and analyzed thematically. Due to the difficulty accessing this population, snowball sampling was used beginning with a volunteer database from a local Hispanic
\end{abstract}

(cc) EY New articles in this journal are licensed under a Creative Commons Attribution 4.0 License. This journal is published by the University Library System, University of Pittsburgh and is cosponsored by the University of Pittsburgh Press. The Journal of Youth Development is the official peer-reviewed publication of the National Association of Extension 4-H Agents and the National AfterSchool Association. 
Leisure Experiences Latino DACA

Alliance. The results support previous literature that has identified constraints this population faces when striving for higher education, as well as the capacity of populations that experience disadvantages for leisure constraint negotiation. The findings show leisure and recreational pursuits support the development of the above mentioned 3-factor support system, helpful in reaching higher education, from previous literature and document a severe drop off of both leisure and recreation participation after high school graduation. Limitations of the study and implications for practice and future research are discussed.

Key words: leisure experiences, Latino, DACA

\section{Introduction}

Young adults without legal immigration status often experience oppression under immigration law in the United States (Mendez-Shannon, 2010). Many of these undocumented students, particularly those between high school graduation and higher education, were brought to the United States by parents or relatives at a young age and now live under extreme oppression without access to continuing education (Gándara \& Contreras, 2009; Mendez-Shannon, 2010; Olivas, 2009; Perez, 2010). Undocumented young adults who apply to institutions of higher education may find laws and constraints related to their enrollment vary from state to state, though the anti-immigrant sentiment is often pervasive (Olivas, 2009).

Recreation, sport, and leisure have been used to create a space to cross social boundaries, dialogue and hope for understanding, collaborate, and work for systemic change (Carlin, 2008; Mandela, 2000; Santos-Gómez, 2010; Wiltse, 2007). Nelson Mandela (2000) made clear that sport can play a role in creating more positive social realities. Höglund and Sundberg (2008) point out that through the opportunity for "collective experience" of sport in South Africa, social lines could be crossed-that sport has the responsibility to contribute to peace building and reconciliation across diverse social boundaries.

Exposure to diverse populations earlier in life has been shown to influence the diversity of a person's social network and one's tolerance for diversity throughout life (Emerson, Kimbro, \&Yancy, 2002; Miller, 2002). Emerson et al. (2002) pointed out that the value of contact between social strata is important for increasing social capital, particularly for groups who are marginalized. Allport (1954) outlined four conditions for this increased social capital: common goals, intergroup cooperation, equal status, and authority support. Recreational therapists have used contact theory as a basis to examine the benefits of inclusive recreational activities for people with disabilities (Devine \& O'Brien, 2007). Its impact has also been examined with respect to gender equality (Lyras \& Hums, 2009). However, there has been little research on 
Leisure Experiences Latino DACA

the use of contact theory in recreational spaces to increase social awareness of the population that is undocumented. The fear of revealing legal status that young adults who are undocumented experience in new and even familiar social settings could be a major constraint to this study (Contreras, 2009; Gonzales, Suárez-Orozco, \& Dedios Sanguineti, 2013; MendezShannon, 2010; Perez, 2010).

Little research exists that addresses the social benefits of leisure and recreation access for students who are undocumented. Little is known about the social interactions of these students, particularly in recreation or leisure settings. While there is research on lack of access to higher education for students who are undocumented, even in the states where students who are undocumented have access to higher education (Olivas, 2009; Mendez-Shannon, 2010), there is little research on how they currently recreate and what constraints influence their leisure choices. Improvements and program development intentionally created to facilitate interactions across social boundaries for students who are undocumented could be supported with this knowledge.

In order to provide some structure around the population for this study, the qualifications for Deferred Action for Childhood Arrivals (DACA) status were used to select participants. DACA is a policy enacted by executive order in June 2012 aimed at providing temporary (renewable on a 2-year basis) eligibility for work permits and relief from deportation to some undocumented young adults in the United States. This study specifically focused on students who are Latino; undocumented; and are eligible for, have applied for, have, or have had DACA status and a work permit. For the purpose of this study, the terms "young adult with DACA status" and "young adult who is undocumented" are used interchangeably. DACA status does not provide a permanent pathway to residency or citizenship for young adults who are undocumented even though it does provide other resources that might not be attainable without this status ("DACA Information," 2019).

The data for this study were collected in late 2014. This study does not account for changes to DACA and the climate or culture surrounding young adults who are undocumented or hold DACA status due to U.S. administrative changes since 2014 when the data were collected.

\section{Purpose}

The purpose of this study was to gain a better understanding of the leisure experiences of young Latino adults who are undocumented. The following research questions were asked: 
Leisure Experiences Latino DACA

- How do young adults who are undocumented engage in recreation and leisure?

- With whom are young adults who are undocumented in contact in these settings?

- What role do these people play in the lives of young adults who are undocumented?

- What is the perceived social climate in these leisure settings?

- What are the perceived constraints on their leisure?

The answers to these questions have potential to help researchers understand and serve young adults who are undocumented.

\section{Literature Review}

Young adults who are undocumented are faced with a challenging transition that Gonzales (2011) described in his article, "Learning to be Illegal." Under the provision of the Plyler v. Doe (1982) Supreme Court case, all children who are undocumented have the right to primary and secondary education, kindergarten through $12^{\text {th }}$ grade. This inherently allows for the protection of these minors from deportation and the realities of being undocumented. As found in numerous studies (Abrego, 2006, 2011; Arbona et al., 2010; Contreras, 2009; Gonzales, 2011; Gonzales \& Chavez, 2012; Rumbaut, 2004), young people may not know they are undocumented or understand the gravity of their situation until certain coming-of-age practices such as getting a driver's license, applying to universities, or trying to get a job.

Several studies have shown that having (a) supportive relationships with adult mentors outside the family; (b) stable, positive community support networks; and (c) regular participation in extracurricular supplementary educational programs have helped youth who are at a disadvantage to cope with their situations and succeed in reaching higher education (Abrego, 2008; Gonzales, 2011; Gonzales \& Ruiz, 2014; Portes \& Fernandez-Kelly, 2008). These three factors will be referred to throughout this study. Research particularly supports the need for extra-family mentorship for young adults who are undocumented and striving for higher education (Abrego, 2008; Gonzales, 2011), and Portes and Fernandez-Kelly (2008) discuss the influence of school structures, extracurricular activity, and teachers as mentors in influencing the educational success of youth who are immigrants and experience many disadvantages. Gonzales (2011) named this time of learning to cope with their lack of immigration documentation the transition to illegality. Essentially, it is the life phase in which students who are undocumented experience a heightened awareness of the constraints on their lives and futures based on their lack of legal status and then learn to cope and change their goals (Gonzales, 2011; Gonzales \& Chavez, 2012). 
Several qualitative studies investigating various life challenges and negotiation report quotes from participants that refer to leisure and recreation settings-such as an informal football league-as areas for networking and stress relief (Gonzales, 2011; Gleeson \& Gonzales, 2012; Mendez-Shannon, 2010). Yet, no research could be found on how leisure activities might help foster these relationships and supportive networks for young people who are undocumented. Recreation and sport create a space to cross and challenge social boundaries; to dialogue; and to create hope for understanding, collaboration, and systemic change (Carlin, 2008; Farquharson \& Marjoribanks, 2003; Kaufman \& Wolf, 2010; Lea-Howarth, 2006; Schulenkorf, 2010).

Research has also revealed that the recreation industry does not always challenge these social boundaries, but instead creates or reinforces them. Research has examined the concept of a "parallel world" in which immigrants often reside. Immigrant presence is necessary in the economic sector, but they are often outcasts from social acceptance (Cravey, 2003; Nelson \& Heimstra, 2008; Smith \& Winders, 2008). Nelson and Heimstra (2008) use the example of the expanding ski resort industry in Colorado. As the mining industry declined and ski resorts grew, nearby towns to Summit County, such as Leadville, experienced an extreme and rapid expansion of Latino residents as the demand for low-wage labor rose. Immigrants live and work alongside the dominant population, but their integration has been neglected (Cravey, 2003; Smith \& Winders, 2008).

Sharaievska, Stodolska, Shinew and Kim (2010) reported that the perceived discrimination of people who are Latino residents in public recreation settings could lead to withdrawal from the activity. Shinew and Floyd (2005) outlined the influence of racial inequality of leisure constraints. They suggested that leisure, as a form of resistance has the potential to play a role in the empowerment of oppressed populations for social change.

Very little research has been done, however, on how young Latino adults who are undocumented engage in recreation. Contact theory (Allport, 1954), introduced earlier in this article, provides a framework for the improvement of relationships between diverse groups. It provides a possible framework to study the impact of recreation and leisure in the lives of young adults who are undocumented.

Pettigrew, Christ, Wagner, and Stellmacher (2007) furthered contact theory by looking at the difference between direct and indirect contact: indirect contact is characterized by "having a 


\section{Leisure Experiences Latino DACA}

friend in the ingroup who has a friend in the outgroup" (p. 411). Given the idea of "parallel worlds" (Cravey, 2003; Nelson \& Heimstra, 2008; Smith \& Winders, 2008), the added benefit of indirect contact could be advantageous for young adults who are undocumented.

Leisure constraint theory, originally developed by Crawford and Godbey in 1987 conceptualized constraints as falling into three categories: interpersonal, intrapersonal, and structural. In 1993, Jackson, Crawford and Godbey added that negotiation of constraints to leisure is possible. Rublee and Shaw (1991) found that constraints to community engagement and leisure participation by Latina women immigrants in Canada negatively influenced the potential benefits for social integration and well-being through these activities.

There has been little research on the use of contact theory or constraint theory in recreational spaces to increase social awareness of the population that is undocumented. While the "1.5 generation" (term coined by Rubén Rumbaut in 1976 to describe the populations of immigrants between the first and second generation) may experience stressors associated with immigrating similar to those experienced by first-generation Korean women in Kim's (2012) study, the population that is undocumented may experience further constraints related to lack of legal immigration status, socio-economic status, and heightened levels of discrimination. The young adults of the 1.5 generation, specifically, may benefit from recreation-based intergroup contact as a way to foster a positive support network that could help them through their transition to fully understanding the reality of their undocumented immigration status. However, as some research notes, the fear experienced by young adults who are undocumented, of revealing legal status in new and even familiar social settings, could be a major constraint (Abrego, 2011; Gonzales, 2011; Gonzales \& Chavez, 2012; Mendez-Shannon, 2010).

\section{Methods}

The purpose of this study was to understand the recreational experiences of young people who are undocumented. Due to the lack of research on this topic, qualitative methods were chosen to allow the voices of the participants to guide the process (Creswell, 2007). Seven young adults who were 18 or older at the time of the study (late 2014), and were without legal citizenship, residency or visa status in the United States were sampled. This study used the eligibility requirements for DACA which served to operationalize the definition of the 1.5generation population in the context of this study. This provided a structure to recruit participants in a particularly hard-to-reach group. In addition to these stipulations, the sample included only young adults who were undocumented and who had a high school diploma. It 


\section{Leisure Experiences Latino DACA}

included students who were enrolled in at least one class in higher education in the fall semester of 2014 for at least part of the semester. Five were enrolled in a 2-year technical college, one was enrolled in a 4-year liberal arts college, and one had recently dropped out of a 2-year technical school mid-semester due to financial issues. All of the participants were between 18 and 21 years old. Characteristics of the sample participants are summarized in Table 1.

The first participants were found by the local Hispanic Alliance, followed by snowball sampling due to the limited and guarded access to the undocumented community. The local Hispanic Alliance coordinated a schedule of interviews and managed participant information to encourage confidentiality.

Table 1. Pseudonyms and Descriptions of Participants

\begin{tabular}{|c|c|c|c|c|}
\hline Pseudonym & $\begin{array}{l}\text { Country of } \\
\text { origin }\end{array}$ & Sex & Main activity & Work \\
\hline Juan $(A)$ & Colombia & Male & Soccer & $\begin{array}{l}\text { Insurance } \\
\text { Agency }\end{array}$ \\
\hline Miguel (B) & Honduras & Male & Rugby & Sale Agency \\
\hline Felipe (C) & Mexico & Male & Drama & Pawn shop \\
\hline Ana (D) & Costa Rica & Female & $\begin{array}{l}\text { Zumba, Beta } \\
\text { Club, Yearbook } \\
\text { Staff, National } \\
\text { Honor Society }\end{array}$ & Restaurant \\
\hline Camila (E) & Colombia & Female & $\begin{array}{l}\text { Beta Club, } \\
\text { Sunday school } \\
\text { teacher, Church } \\
\text { youth retreats }\end{array}$ & $\begin{array}{l}\text { Consulting } \\
\text { Agency }\end{array}$ \\
\hline Alberto (F) & Mexico & Male & $\begin{array}{l}\text { Photography, } \\
\text { Videography, } \\
\text { Art/Drawing }\end{array}$ & Tire Center \\
\hline Sara (G) & Mexico & Female & $\begin{array}{l}\text { Advocacy, } \\
\text { Community } \\
\text { Service }\end{array}$ & Retail \\
\hline
\end{tabular}




\section{Leisure Experiences Latino DACA}

\section{Data Collection}

Semi-structured interviews were conducted based on the 3-step Seidman (2012) approach to understand the participants' recreational experiences. Interviews started with a background and life history, and then moved to a detailed description of their recreation participation and the social environment surrounding their recreational experiences. A sociogram was used to assist with discussion, show different layers of social connections in the participant's life, and encourage reflection on social connections in recreational settings. At the beginning of each interview participants were asked to write a brief description of influential mentors, family, and friends in their lives. They were asked to place these descriptions within the sociogram, depicted as a set of concentric circles. The innermost circles represent relationship that students identified as most important and the outermost circle identified important acquaintances, peers, or friends. Essentially, this served as a visual guide for the interview.

The participants agreed and all the interviews were audio recorded for transcription, review, and analysis. To protect the identity of the participants, interviews were conducted at the University Center, thus eliminating the need to collect participant addresses. The center provided a neutral, quiet, and safe area. A member of the staff at the local Hispanic Alliance was responsible for contacting participants so the research project did not need to have access to phone numbers. All names were changed and any identifying information was eliminated in order protect the confidentiality of the participants.

\section{Data Instrument}

As the interviewer in qualitative research, the first author was the data collection instrument. She used a reflexivity journal during the research process in order to record her own thoughts, reactions, and biases throughout the process. Dupuis (1999) points out in qualitative research, that rather than removing ourselves from the research when telling the story of others, embracing both the research self and human influence helps us maintain authenticity throughout the process. The interviewer worked to use reflexive journaling as a way to recognize her own reactions to maintain that authenticity, but also acknowledge the impact of her thoughts on trustworthiness. This delineation also helped her execute this research in a way that honors this population, who is marginalized, and recognizes that the interviewer is an outsider as a White woman working on a master's degree.

The data collected from the interviews were later considered with researcher notes, memos, and reflexive journal. Member checking was encouraged with all participants and three 


\section{Leisure Experiences Latino DACA}

participated. English was used in the interviews in order to avoid losing any meaning in translation. If a participant used a word in Spanish or another language, they were asked to give a definition in English during the interview.

One outside researcher was asked to provide external auditing during and after the coding process according to Creswell (2009). The auditor reviewed the codes. Less than $20 \%$ of the coding decisions were questioned. Any questioned decisions were discussed until consensus was reached between the auditor and researcher. Another researcher was asked to do peer debriefing in line with Creswell (2009). The peer researcher asked questions about the study and looked through all the codes, topics, and themes asking questions to understand and clarify the decisions, aiding the trustworthiness through data analysis.

\section{Data Analysis}

Data analysis began during the continued collection of interviews. This allowed the interviewer to identify any further questions that needed to be asked in remaining interviews. All of the interviews were transcribed verbatim. Open coding was used to organize the data. Codes based on the three factors related to community support, extra-familial mentors, and dedicated extracurricular participation were developed before coding any data as these codes had arisen on numerous occasions during the data collection process. Then, axial coding was used to group the open codes into categories and identify topics. Selective coding was used to identify themes from the topics identified through axial coding.

\section{Findings}

One important finding from this study is when constraints to leisure are negotiated, leisure participation leads to the three factors shown to help in reaching success in higher education. These factors are dedicated participation in extracurricular activities, building a supportive community, and establishing extra-familial mentors. All of the students who participated in this study were actively engaged in leisure and/or recreational extracurricular activities in high school. These varied widely from photography and videography for their church, to soccer or other sports, to civic engagement and community service clubs. During high school, the social connections from these activities played an important role in the students' lives, either enriching previously established relationships or providing a setting to build new relationships with both peers and mentors. 
Each participant was active in a variety of activities, but typically more dedicated to one high school activity. Juan played soccer in his neighborhood as a small child, throughout elementary school, middle school, and all 4 years of high school. Miguel played soccer until the freshman year of high school when he transferred to the rugby team with others he knew from soccer. He played on the rugby team all 4 years of high school. Felipe was actively involved with both drama classes and drama productions all 4 years of high school. Ana was in Beta Club for 3 years of high school, which encouraged her to fulfill leadership roles in other school clubs such as the recycling club and the yearbook team. Camila was highly involved with the children in her church and faith-based youth conventions and fellowship opportunities. Alberto was involved with art classes all 4 years of high school and ran all the photography and videography for his church. Sara played soccer all 4 years in addition to being highly involved in numerous civic and community service organizations.

Each of the students mentioned participating in leisure and recreation activities with close friends. Miguel said,

[Rugby is] actually the love of my being. Like I said, I played several things in high school and it was fun. It was really, really fun, but once I started getting to know everybody, it became more of, instead of just a game, it became like a bond or whatever.

Some participants mentioned choosing activities with their closest friends more often, which as Sara pointed out, "[The leisure activity] definitely enriched [friendships] because we shared memories, you know. Common high school stuff." Ana, when describing her participation in the recycling club and yearbook, responded,

My two best friends were in the recycling club senior year of high school. My biology teacher-which kind of got me into biology, too-he played an important role. Basically we have maybe 20 members . . . actually one of my best friends, $L G$, I met her in third grade so we go way back, and I was the one that got her into recycling club. I was like hey, this is going to benefit you. You're going to get your hours. So she started doing it. And then my other friend, YP, I met her my freshman year of high school, and I also got her into that. 


\section{Leisure Experiences Latino DACA}

Other participants suggested that they both made new friends and built on older friendships in leisure and/or recreation pursuits. Juan explained,

$J G$, he's a friend of mine. I met him in middle school. He went to the same middle school that I did. We played soccer in middle school. . . . He went to a rival high school of mine, but we were still friends at the time. We played soccer against each other and now we go to the same college at Tech. ... But I've known him for a while and he's a very cool guy. He's a good friend.

Juan grew up playing soccer in the parking lot of his apartment complex with anyone who would play, and continued to build those relationships from childhood soccer throughout his life, sometimes adding new friends such as JG. Alberto said it clearly: "The time that we spent together bonding in different activities. I guess that really made it really strong; when I introduced him to one of my hobbies, and what I really like doing."

Many of the participants cited leisure and recreation in helping them establish a supportive community during their high school years. Miguel said of his rugby team,

It's a lot of people. Like I said, it was kind of different because we as a whole were really close, but some were closer than others. So for example, the whole game is split out into between backs. . . and forwards, which is what I was... so all the forwards kind of just work together, and all the backs were kind of just together, but there was obviously more . . . there was some intermingling of course. We were all just really close.

All the students who played sports mentioned this sentiment of team camaraderie; however, even those who participated in other leisure pursuits mentioned support from groups where they participated in leisure activity. For example, Felipe refers to road tripping with a small group of friends he met primarily through family connections and drama activities,

With the friends I have, we support each other, and we ended up doing it together, and it was a lot easier going with them instead of going alone. When everything went bad, you still have them as backup. That made the trip.

In addition to the supportive communities these young adults formed through extracurricular leisure and recreation activities, they often described finding mentors in the adult leaders of 
Leisure Experiences Latino DACA

these activities. Mentors were described as teachers who also facilitated extracurricular clubs or sports, coaches, pastors and even a lawyer that helped file the paperwork for a DACA permit. Sara talked about her primary mentors:

She was actually my history teacher and we had been together because of the IB diploma program I was in. We had her for two years and I had known her since freshman year because of [the club], and her name was Mrs. P. She's been a major help. . . . She was always the teacher that I could go to and cry and just go sit with her, and if we ever needed anything she was there. . . My English teacher Mrs. A, she's from __, she's also a feminist, but she also loves fighting for justice. And I taught both of them what $D A C A$ meant and ever since then they've been trying to reach out to DACA-mented students and help out.

Further explaining the impact of her mentors, Sara said, "My teachers were there too, oh my gosh, my teachers helped me so much. Always giving me words of encouragement and never letting me give up."

In contrast, Felipe felt like he didn't have any mentors in high school among his teachers, advisors or coaches, but he talked extensively about a mentor he was matched with in a middle school mentor program:

He embedded that idea of going to college at a young age. He was there, "Hey you should go to college. I went to the University of XYZ and I got a degree in communications." . . They want the best. They want you to go to college, but they really have no clue. It's a surreal idea. So they give you the idea of going, but they don't give you a guide or a walkthrough of how it's going to be or what it should be like.

Felipe, even though he had to drop out in the middle of the semester for financial reasons still talks about going back-to be the first college graduate in his family and to set an example for his younger brother.

Most participants articulated that they saw the link between their leisure pursuits and reaching higher education through developing supportive community networks, relationships with extrafamilial mentors, and participating in extracurricular activities. However, most participants began to see a shift in their leisure participation after high school graduation, which had a negative impact on the three factors that help young adults who are undocumented cope with 


\section{Leisure Experiences Latino DACA}

their situation and reach for higher educations. When constraints to leisure are negotiated, leisure participation leads to dedicated participation in extracurricular activities, building a supportive community and establishing extra-familial mentors. These young adults experience constraints to leisure participation - often related to time, financial stress, and transportationwhich severely increase after high school.

\section{Discussion}

The purpose of this study was to gain a better understanding of the leisure experiences of young adults with DACA status. This study began based in contact theory, but the data links did not show changes in tolerance and discrimination as a result of contact between social strata in leisure participation. As discussed in the literature review contact theory states that interaction with diverse populations improves the diversity of social networks and tolerance of different social groups (Allport, 1954; Emerson et al., 2002). This theory originally developed in 1954 does not account for current issues, restrictions and limitations due to immigration status. While a few participants mentioned diversity and lessened levels of discrimination in soccer and rugby, this was not a pervasive theme throughout the data. Discrimination, stereotypes, and stereotype threat definitely arose in the data, but the premise of contact theory-building acceptance and tolerance-was only seen in a few examples of soccer (Juan and Sara) and rugby (Miguel). The findings of this study are in line with and extend other previous literature.

The findings of this study show the influence of leisure and recreation pursuits in developing and enriching supportive community networks, relationships with extra-familial mentors, and dedicated participation in extracurricular activity in line with previous research literature (Abrego, 2008; Gonzales, 2011; Gonzales \& Ruiz, 2014; Portes \& Fernandez-Kelly, 2008; Zhou, 2008). The positive influence of mentorship from teachers, counselors, coaches, and pastors on higher education closely reflects the findings from previous studies (e.g., Portes \& FernandezKelly, 2008; Gonzales, Suárez-Orozco, \& Dedios-Sanguineti, 2013), which all found the role of these mentors is essential. Without these mentors with whom the students can talk about their situations freely, and who motivate and encourage the students when they face disappointments and constraints, the pursuit of educational and occupational success would be constrained. Similarly, this study showed that relationships with friends and peers in supportive community networks were formed during high school years and provided motivation and encouragement that was key to sustained engagement and the successful pursuit of higher education (Abrego, 2008; Gonzales, 2011; Gonzales \& Ruiz, 2014; Stanton-Salazar, 2001). This 


\section{Leisure Experiences Latino DACA}

study revealed that many of these relationships with both mentors and peers are developed while participating in extracurricular leisure and recreation activities.

\section{Implications for Future Research}

The findings of this study reveal that young adults with DACA status experience leisure constraints similar to other populations that experience disadvantages, but are further impacted by their immigration status. Future research is needed to understand the complexities of this population's leisure constraints and their negotiation ability.

Crawford and Godbey (1987) originally expressed constraints in three categories: interpersonal, intrapersonal, and structural. Jackson et al. (1993) theorized about the ability of individuals to negotiate their constraints to leisure. Stodolska and Yi-Kook (2005) pointed out the connections between the marginality, ethnicity, and discrimination framework with leisure constraint theory. This was noted especially in the lives of minority groups who (a) do not have the same access to resources such as education and income (marginality); (b) live with different cultural traditions, such as family-oriented values (ethnicity/culture); and (c) experience oppressive social tendencies, such as stereotyping and stereotyped threats (discrimination). In the context of this population, further research is needed to understand how interpersonal, intrapersonal, and structural constraints interact with the marginality, ethnicity, and discrimination framework in the context of leisure.

Future research could overlay constraint theory and the three support system factors discussed in the literature review: community support, extracurricular activity, and extra-familial mentors (Abrego, 2008; Gonzales, 2011; Gonzales \& Ruiz, 2014; Portes \& Fernandez-Kelly, 2008; Zhou, 2008). Combining these concepts, future research could examine the impact of leisure constraint negotiation on continued development of the three social support factors throughout higher education.

For future research, it is important to acknowledge that leisure participation is likely one of many avenues for young adults who are undocumented to develop supportive community networks, engage in extracurricular activities, and build relationships with extra-familial mentors. Further research would be needed to understand the role of leisure in the overall support structure of young adults with DACA status. 


\section{Implications for Practitioners}

As a reflection of the data, three areas of practical application for this research knowledge are proposed: (a) the intentional design of community and high school programs to build mentorship opportunities across social strata; (b) diversity and inclusion training for coaches, teachers, and school club advisors to feel supported and prepared to help groups of students bond and grow into supportive communities; and (c) the creation of low-cost, lower timecommitment avenues to enable students to continue social leisure pursuits after moving on to higher education and maintain the three-factor support system throughout their studies.

This study documents that strong mentors are a vital piece of the three-factor support system that helps students who are at a disadvantage reach higher education. Programs could include one-on-one activities or regular small group meetings with coaches, club advisors or teachers. These programs could take a holistic approach to allow mentor and mentee to get to know and trust one another fully, such that the mentee has a safe place to reveal the deep and often hard-to-discuss challenges faced in thinking about or reaching for higher education.

This study documents that the need for these young adults who have DACA status to be able to reveal themselves and their life experiences authentically and fully to their mentors and supportive community network is vital. The experiences and barriers they face can be overwhelming and shocking to others who may not have related experience. Diversity and inclusion training can help mentors and community members learn how to be good allies and help their fellow community mentors foster alliances with mentees in their pursuit of higher education.

This study documents that leisure and recreation pursuits do provide an avenue for the three factors that help young adults who are at a disadvantage achieve higher education. It also notes that after attaining enrollment, leisure and recreational participation drops off to the detriment of these three factors. Development of (or clear advertisement of existing) well placed, low-time-commitment, low-cost, socially-based leisure pursuits could help this population maintain or build new supportive community networks, relationships with extrafamilial mentors, and dedicated participation in extracurricular activities. This could help young adults with DACA status maintain momentum and stamina to complete their higher education studies. 
Leisure Experiences Latino DACA

This study documents that leisure and recreation participation in high school encouraged the engagement in extracurricular activity, development of supportive community networks, and relationships with extra-familial mentors and that leisure participation is more constrained after high school graduation for various reasons, including time and financial stress. The findings of this study reveal three other areas for future research including the impact of differing state laws, stereotyping of the Latino community, and identifying as a first-generation college student within one's family. Further research is necessary to understand the impact of DACA on constraint negotiation in different states and how varying state laws impact these young adults. Several participants also mentioned the influence of the negative stereotypes of both the Latino community and undocumented immigrants. Further research to understand the impacts of these stereotypes and how underlying stereotype threat affects enrollment and success in higher education. Many of these young adults are the first in their family to strive for higher education. Future research could extend existing literature on the impact of undocumented status on first-generation college students. Research could assess the role of leisure and recreation in negotiating these multiple identities.

The limitations of this study included sample size, methodological limitations, and the researcher's demographic characteristics. A noted limitation of this study was the difficulty in recruiting participants. As the study was exploratory in nature, more studies will need to be conducted with larger sample sizes.

Some participants were clearly comfortable talking to the researcher. They shared stories freely with vivid detail and confidence. Others were clearly hesitant to talk very deeply about the issues they face in both leisure and the pursuit of higher education. It was clear that the young adults' DACA status and the researcher's history working in immigration advocacy provided some level of rapport and reduced fear. However, personal biases (of the researcher) from working in immigration advocacy may have influenced the data in spite of careful attention to calibrating for these biases throughout the study. Even with these challenges, the data that were collected both confirmed past research literature and provided information for further research. Recreation professionals can facilitate the development of important supportive community environments and ally networks for these young adults through providing inclusive leisure recreation opportunities that account for time and financial constraints as well as the desire to challenge themselves to grow during emerging adulthood.

Leisure and recreation researchers can facilitate the strengthening of supportive community networks, meaningful bonds with extra-familial mentors, and dedicated participation in 
Leisure Experiences Latino DACA

extracurricular activity. This study illustrates what leisure and recreation researchers already know-that the field influences all facets of life. The information described in this study can encourage the development of leisure and recreation facilities and educate the broader field of youth development. When leisure and recreation are constrained, the impact is felt by each individual and the greater community. Youth development professionals have the capacity to support these young adults who have been marginalized in their communities to strive for better lives. The social sciences have the capacity to collectively address policy issues through creative and engaging research and community development.

\section{Acknowledgements}

We would like to give a special thanks to the local Hispanic Alliance for their hard work, flexibility, and insight throughout this research. We are grateful for the participants and their willingness to share parts of their heart-wrenching and inspiring stories.

This study is part of a larger thesis document completed as part of the first author's master's degree.

\section{References}

Abrego, L. J. (2006). "I can't go to college because I don't have papers": Incorporation patterns of Latino undocumented youth. Latino Studies, 4(3), 212-231. doi:10.1057/palgrave.Ist.8600200

Abrego, L. (2008). Legitimacy, social identity, and the mobilization of law: The effects of Assembly Bill 540 on undocumented students in California. Law \& Social Inquiry, 33(3), 709-734.

Abrego, L. J. (2011). Legal consciousness of undocumented Latinos: Fear and stigma as barriers to claims-making for first-and 1.5-generation immigrants. Law \& Society Review, 45(2), 337-370. doi:10.1111/j.1540-5893.2011.00435.x

Allport, G. W. (1954). The nature of prejudice. Cambridge: Addison Wesley.

Arbona, C., Olvera, N., Rodriguez, N., Hagan, J., Linares, A., \& Wiesner, M. (2010). Acculturative stress among documented and undocumented Latino immigrants in the United States. Hispanic Journal of Behavioral Sciences, 32(3), 362-384. doi:10.1177/0739986310373210

Carlin, J. (2008). Playing the enemy: Nelson Mandela and the game that made a nation. New York, NY: Penguin. 
Contreras, F. (2009). Sin papeles y rompiendo barreras: Latino students and the challenges of persisting in college. Harvard Educational Review, 79(4), 610-632. doi:10.17763/haer.79.4.02671846902gl33w

Cravey, A. J. (2003). Toque una ranchera, por favor. Antipode, 35(3), 603-621. doi:10.1111/14678330.00341

Crawford, D. W. \& Godbey, G. (1987). Reconceptualizing barriers to family leisure. Leisure Sciences, 9, 119-127. doi:10.1080/01490408709512151

Creswell, J. W. (2007). Qualitative inquiry and research design: Choosing among five approaches. Thousand Oaks, CA: Sage.

DACA Information. (2019, February). Retrieved from University of California at Berkeley website: https://undocu.berkeley.edu/legal-support-overview/what-is-daca/

Devine, M.A. \& O'Brein, M. B. (2007). The mixed bag of inclusion: an examination of an inclusive camp using contact theory. Therapeutic Recreation Journal, 41(3), 201-222.

Dupuis, S. L. (1999). Naked truths: Towards a reflexive methodology in leisure research. Leisure Sciences, 21(1), 43-64. doi:10.1080/014904099273282

Emerson, M. O., Kimbro, R. T., \& Yancey, G. (2002). Contact theory extended: The effects of prior racial contact on current social ties. Social Science Quarterly, 83(3), 745-761.

Farquharson, K., \& Marjoribanks, T. (2003). Transforming the Springboks: Re-imagining the South African nation through sport. Social Dynamics, 29(1), 27-48. doi:10.1080/02533950308628649

Gándara, P. C., \& Contreras, F. (2009). The Latino education crisis: The consequences of failed social policies. Cambridge, MA: Harvard University Press.

Gleeson, S. \& Gonzales, R. G. (2012). When do papers matter? An institutional analysis of undocumented life in the United States. International Migration, 50(4), 1-19.

Gonzales, R. G. (2011). Learning to be illegal: Undocumented youth and shifting legal contexts in the transition to adulthood. American Sociological Review, 76(4), 602-619. doi: $10.1177 / 0003122411411901$

Gonzales, R. G., \& Chavez, L. R. (2012). "Awakening to a nightmare": Abjectivity and illegality in the lives of undocumented 1.5-generation Latino immigrants in the United States. Current Anthropology, 53(3), 255-281.

Gonzales, R. G., \& Ruiz, A. G. (2014). Dreaming beyond the fields: Undocumented youth, rural realities and a constellation of disadvantage. Latino Studies, 12(2), 194-216. doi:10.1057/Ist.2014.23

Gonzales, R. G., Suárez-Orozco, C., \& Dedios-Sanguineti, M. C. (2013). No place to belong: Contextualizing concepts of mental health among undocumented immigrant youth in the United States. American Behaviora/Scientist, 57(8), 1174-1199. doi:10.1177/0002764213487349.

Höglund, K., \& Sundberg, R. (2008). Reconciliation through sports? The case of South Africa. Third World Quarterly, 29(4), 805-818. 
Jackson, E. L., Crawford, D. W. \& Godbey, G. (1993). Negotiation of leisure constraints. Lesiure Sciences, 15, 1-11. doi:10.1080/01490409309513182

Kaufman, P., \& Wolff, E. A. (2010). Playing and protesting: Sport as a vehicle for social change. Journal of Sport \& Social Issues, 34(2), 154-175. doi:10.1177/0193723509360218

Kim, J. (2012). Exploring the experience of intergroup contact and the value of recreation activities in facilitating positive intergroup interactions of immigrants. Leisure Sciences, 34(1), 72-87. doi:10.1080/01490400.2012.633856

Lea-Howarth, J. (2006). Sport and conflict: Is football an appropriate tool to utilise in conflict resolution, reconciliation or reconstruction? Unpublished master's dissertation, University of Sussex, Brighton, UK. Retrieved from https://www.sportanddev.org/sites/default/files/downloads/42_sport_and_conflict_reconciliation ma_dissertation.pdf

Lyras, A., \& Hums, M. A. (2009). Sport and social change: The case for gender equality. Journal of Physical Education, Recreation \& Dance, 80(1), 7-21. doi:10.1080/07303084.2009.10598256

Mandela, N. (2000). Speech from the Laureus Lifetime Achievement Awards. Monaco. Available from https://www.youtube.com/watch?v=GdopyAFPODI

Mendez-Shannon, E. C. (2010). "We will always be in the shadows" - A qualitative descriptive study of undocumented Latino immigrants surviving in the United States (Unpublished doctoral dissertation). University of Iowa, Iowa City.

Miller, N. (2002). Personalization and the promise of contact theory. Journal of Social Issues, 58(2), 387410. doi: $10.1111 / 1540-4560.00267$

Nelson, L., \& Hiemstra, N. (2008). Latino immigrants and the renegotiation of place and belonging in small town America. Social \& cultural geography, 9(3), 319-342. doi:10.1080/14649360801990538

Olivas, M. A. (2009). Undocumented college students, taxation, and financial aid: A technical note. The Review of Higher Education, 32(3), 407-416. doi:10.1353/rhe.0.0068

Perez, W. (2010). Higher education access for undocumented students: Recommendations for counseling professionals. Journal of College Admission, 206, 32-35.

Pettigrew, T. F., Christ, O., Wagner, U., \& Stellmacher, J. (2007). Direct and indirect intergroup contact effects on prejudice: A normative interpretation. International Journal of Intercultural Relations, 31(4), 411-425. doi:10.1016/j.ijintrel.2006.11.003

Plyler v. Doe, 457 U.S. 202 (1982). Retrieved from http://caselaw.Ip.findlaw.com/cgibin/getcase. pl?court=us\&vol=457\&invol $=202$

Portes, A., \& Fernández-Kelly, P. (2008). No margin for error: Educational and occupational achievement among disadvantaged children of immigrants. The Annals of the American Academy of Political and Social Science, 620(1), 12-36. doi:10.1177/0002716208322577 
Journal of Youth Development | http://jyd.pitt.edu/ | Vol. 14 Issue 2 DOI 10.5195/jyd.2019.704

Leisure Experiences Latino DACA

Rublee, C. B., \& Shaw, S. M. (1991). Constraints on the leisure and community participation of immigrant women: Implications for social integration. Loisir et société/Society and Leisure, 14(1), 133-150. doi:10.1080/07053436.1991.10715376

Rumbaut, R. G. (2004). Ages, life stages, and generational cohorts: Decomposing the immigrant first and second generations in the United States. International Migration Review, 38(3), 1160-1205.

Santos Gómez, H. J. H. (2010). California rural communities, farm worker settlement and citizenship practices: Playing soccer in the San Joaquin Valley (unpublished doctoral dissertation) University of California, Santa Barbara.

Schulenkorf, N. (2010). Sport events and ethnic reconciliation: Attempting to create social change between Sinhalese, Tamil and Muslim sportspeople in war-torn Sri Lanka. International Review for the Sociology of Sport, 45(3), 273-294. doi:10.1177/1012690210366789

Seidman, I. (2012). Interviewing as qualitative research: $A$ guide for researchers in education and the social sciences. New York, NY: Teachers college press.

Sharaievska, I., Stodolska, M., Shinew, K. J., \& Kim, J. (2010). Perceived discrimination in leisure settings in Latino urban communities. Leisure/Loisir, 34(3), 295-326. doi:10.1080/14927713.2010.521319

Shinew, K. J. \& Floyd, M. F. (2005). Racial inequality and constraints to leisure in the post-civil rights era: Toward an alternative framework. In E. L. Jackson (Ed.), Constraints to leisure (pp. 35-51). State college, PA: Venture.

Smith, B. E., \& Winders, J. (2008). 'We're here to stay': Economic restructuring, Latino migration and place-making in the US South. Transactions of the Institute of British Geographers, 33(1), 60-72.

Stanton-Salazar, R. D. (2001). Manufacturing hope and despair: The school and kin support networks of US-Mexican youth. New York, NY: Teachers College Press.

Stodolska, M. \& Yi-Kook, J. (2005). Ethnicity, immigration, and constraints. In E. L. Jackson (Ed.), Constraints to leisure (pp. 53-73). State College, PA: Venture.

Wiltse, J. (2007). Contested waters: A social history of swimming pools in America. Chapel Hill: University of North Carolina Press.

Zhou, M. (2008). The ethnic system of supplementary education: Nonprofit and for-profit institutions in Los Angeles' Chinese immigrant community. In M. Shinn \& H. Toshikawa (Eds.), Toward positive youth development: Transforming schools and community programs, (pp. 229-251).

doi:10.1093/acprof:oso/9780195327892.003.0013 